\section{The effects on chronic periodontitis of a \\ subgingivally-placed redox agent in a slow release device}

Ower PC, Ciantar M, Newman HN, Wilson M, Bulman JS: The effects on chronic periodontitis of a subgingivally-placed redox agent in a slow release device. $J$ Clin Periodontol 1995; 22: 494-500. (c) Munksgaard, 1995.

Abstract. Adjunctive chemical agents can reduce the need for meticulous plaque control. The aim of this investigation was to evaluate the periodontal treatment potential of subgingival application of the redox agent methylene blue in a slowrelease device. This randomized, single-blind, split-mouth study included $18 \mathrm{pa}-$ tients aged 35-57 years, with chronic adult periodontitis. pocketing of at least 5 $\mathrm{mm}$ and radiographic evidence of regular bone loss. All experimental sites received subgingival debridement at day 0 . Test sites received $32 \% \mathrm{w} / \mathrm{w}$ methylene blue in the slow release device at days 0 and 28. Clinical examination and microbiological sampling were performed at days $0,7,28,56$ and 84. Clinical improvements were seen in both groups, but test sites showed consistently greater improvements, some of which were statistically significant (as determined by between-group comparisons utilising SNDs). Significant between-group differences in relation to baseline levels were seen in bleeding index at days 7 and 56, in probeable pocket depth at day 56 and for the Perioscan BANA test at day 7. This pilot study thus showed that adjunctive methylene blue in a slow-release device can produce greater clinical and microbiological improvements than subgingival debridement alone.

\author{
P.C. Ower ${ }^{1}$, M. Ciantar' \\ H. N. Newman ${ }^{1}$, M. Wilson ${ }^{2}$ and \\ J. S. Bulman ${ }^{3}$
}

Departments of ${ }^{1}$ Periodontology, ${ }^{2}$ Microbiology and ${ }^{3}$ Dental Health Policy, Eastman Dental Institute for Oral and Dental Health Care Sciences, University of London, 256 Gray's Inn Road, London WC1X 8LD, UK

Key words: chronic periodontitis; subgingival plaque; redox potential; methylene blue

Accepted for publication 20 June 1994
An alternative approach to conventional antimicrobial or antiseptic agents in the suppression of subgingival bacteria is to inhibit their growth by changing the subgingival environment, which has been shown to be highly anaerobic with a prevailing low oxygen tension (Loesche et al. 1983, Mettraux et al. 1984). This has in the past led to the concept of oxygenating the periodontal tissues as a means of therapy, a concept that has been periodically revived since first advocated by Dunlop (1913). Such agents have been applied as molecular oxygen (Box 1937. Hirsch et al. 1981), hyperharic oxygenation (Guentherman et al. 1972, Gotsko et al. 1980, Sumachev 1983), hydrogen peroxide (Slanetz \& Brown 1946, Keyes et al. 1978a, 1978b, 1982a, 1982b, Rosling et al. 1983, Baer et al. 1985) and urea peroxide (Shipman et al. 1971, Shapiro et al. 1973, Kaslick et al. 1975). Results have been variable, with the agents often causing undesirable side-effects or being lost from the pockets too quickly to be effective. The subgingival environment, however, has also been shown to have a very low redox potential (Kenney \& Ash 1969, Marsh \& Martin 1984). A low redox potential (Eh) is an essential component of an ecosystem supporting the growth and survival of subgingival anaerobic bacteria (Smith \& Williams 1984, Finegold 1989). Many anaerobes will not survive if the $\mathrm{Eh}$ is too high, even in the absence of oxygen (Socransky et al. 1964, Aranki et al. 1969, Marsh \& Martin 1984), and some will grow in the presence of oxygen pro- vided the Eh is maintained at a low level (Steiner et al. 1981). An increase in the $\mathrm{Eh}$ of the subgingival environment should therefore adversely affect anaerobic bacteria and this hypothesis formed the basis of two recent studies investigating the potential therapeutic effect of the redox agent methylene blue in a small group of patients with chronic periodontitis (Wilson et al. 1992, Gibson et al. 1992). The aim of the present study was to further investigate the clinical and microbiological effects of this agent using a subgingivally-placed slow release device.

\section{Material and Methods}

20 patients attending the Department of Periodontology, Eastman Dental In- 
stitute, were admitted to the trial. The patients met the following criteria:

1. Aged 35-65 years.

2. No relevant medical history.

3. No antibiotic therapy or use of oral antiseptics in the previous 3 months.

4. Females not pregnant.

5. At least 2 separate proximal pockets on contralateral sides $\geq 5 \mathrm{~mm}$, and anterior to the mesial surfaces of the second molars.

6. No buccal or lingual pocketing.

7. Bleeding on probing.

8. Radiographic evidence of alveolar bone loss.

\section{Study design}

This was a randomized, single-blind study, utilizing a split-mouth design. On selection, following an explanation of the nature of the study and after voluntary, informed, written consent, patients received basic oral hygiene instruction in the form of modified Bass brushing. This instruction, and all subsequent clinical and microbiological assessments, were performed by the same operator ( $\mathrm{PCO}$ ). No special instruction was given in interproximal cleaning. $\mathrm{Pa}$ tients were requested to refrain from using any commercially available mouthwashes during the study. The experimental sites were then selected.

Approximately 6 weeks later, baseline measurements of clinical and microbiological variables were made (day 0 ). Each patient then received a single-visit subgingival debridement of all experimental sites. The redox agent was then applied. by a hygienist, to the experimental sites on the test side of the mouth. The redox agent used in this study was $32 \% \mathrm{w} / \mathrm{w}$ methylene blue, incorporated in a biocompatible and biodegradeable composite material made of collagen, polyglactin 910 (Vicryl) and alginate. The test side was determined by a computer-generated random code which allocated test and control sides to each study number. $\mathrm{Pa}$ tients were subsequently seen on days 7 , 28, 56 and 84 when all variables were reassessed. At day 28 , patients received from the hygienist a second application of the redox agent at the test sites, but no further instrumentation.

\section{Clinical variables}

The following clinical variables were assessed for each experimental site during the course of the study, using a parallel- sided EN 15 probe (Ash Dentsply, Surrey, UK) with a $0.5 \mathrm{~mm}$ tip and tine diameter and $1 \mathrm{~mm}$ gradations:

(a) Plaque index (PII: Silness \& Löe 1964).

(b) Bleeding on probing (BOP): probing to the pocket base and using the criteria of the papilla bleeding index (Saxer \& Mühlemann 1975).

(c). Probeable pocket depth (PPD): to the nearest (rounded up) $\mathrm{mm}$.

\section{Microbiological variables}

At each visit, subgingival plaque samples from test and control sites were assessed for their ability to hydrolyse benzoyl arginine naphthylamide (BANA) using a chairside test (Perioscan, Oral-B Laboratories, USA). A positive result in this test has been shown to correlate with the presence of one or more of the periodontopathic organisms Porphyromonas gingivalis, Treponema denticola and Bacteroides forsythus. Subgingival plaque samples were collected from each experimental site by curette and placed on the Perioscan reagent card. Following incubation at $55^{\circ} \mathrm{C}$ for $15 \mathrm{~min}$, the titre of the target organisms present was assessed, each site being scored positive (high numbers of BANA-hydrolysing organisms present), weak positive or negative (low numbers of BANA-hydrolysing organisms present).

\section{Statistical analyses}

Reproducibility data for PII and BOP were assessed by means of Cohen's $k$ ppa (Cohen 1960) and for PPD using a method proposed by Bland \& Altman (1986), in which the differences between the sums of measurements taken at a number of randomly selected sites in a small number (6) of subjects at 2 different time-points were plotted against the means of these sums; then by determining the mean of the difference, together with $95 \%$ confidence intervals for both the mean and individual differences, the maximum possible error that could be expected for the index could then be assassed.

Site data vere used for purely descriptive purposes while subject data were used for all statistical analysis. Baseline differences between the groups were significance tested by applying $\chi^{2}$ tests to the frequency data, at baseline, for each index (PII, BOP and BANA test) and for pocket depth (whole $\mathrm{mm}$ ).
For all variables the site data were described in terms of the percentage of sites improving, not changing or deteriorating at each time point when compared to baseline, and regardless of the level of change. Thus, for PII, BOP and BANA test, any change in level for these variables at individual sites, compared to baseline. was recorded as an improvement or a deterioration, while for PPD a change in depth of a whole $\mathrm{mm}$ or more would constitute a change and be recorded similarly.

Subject-based $2 \times 2$ contingency tables were then drawn up for each variable at each time-point, in which the subject data were derived from an analysis of the total number of sites per subject showing improvement or deterioration on both test and control sides, weighted to compensate for the varying number of test and control sites in each subject. SND $(Z)$ tests were then employed to compare the proportions showing improvement between test and control groups, since the sample sizes justified the use of normal distribution statistical analysis on the binomial data under review, especially with the inclusion of a continuity correction:

$$
\operatorname{SND}(Z)=\frac{\left({ }^{\prime} p_{1}-p_{2}^{1}\right)-\frac{1}{2}\left(1 / n_{1}+1 / n_{2}\right)}{\operatorname{EST} \cdot \operatorname{SE}\left(p_{1}-p_{2}\right)}
$$

\section{Results}

Consistency data

Intra-examiner error was assessed for PII. BOP and PPD prior to the start of the study: 50 approximal sites were randomly selected in several patients and examined at 2 time-points, separated by approximately $30 \mathrm{~min}$. For PlI and BOP $h$-values of 0.89 and 0.65 , respectively, were obtained, while for PPD a maximum possible error of $9.0 \%$ was found.

\section{Baseline data}

Of the 20 patients who entered the study. one was withdrawn due to a periodontal abscess and another failed to attend the final visit. There were 11 male and 7 female subjects, aged 35-57 years (mean 43.9 years). Since as many suitable sites as possible were used in each subject, the number of test and control sites varied between subjects. Test sites totalled 71 (mean 3.9 per patient) and control sites 79 (mean 4.4 per patient). Experimental sites did not exceed $9 \mathrm{~mm}$ in probeable pocket depth. 
Table 1. Significant differences in favour of the test group during the study period

\begin{tabular}{lrr}
\hline Variable & Day & SND \\
\hline PII & 7 & 2.877 \\
& 84 & 2.559 \\
BOP & 56 & 3.278 \\
PPD & 56 & 2.447 \\
BANA & 7 & 2.776 \\
\hline
\end{tabular}

control at the main approximal risk sites, so it was important that subjects carried out a practical daily cleaning regime that they might be expected to maintain in the long term. At the outset the subjects were given basic oral hygiene advice but no instruction in interproximal plaque control. Thus the effects of the test agent could be assessed in patients who exercised the type of daily oral hygiene regime likely to be employed by the majority of the population.

Redox potential is a measure of the reducing power of a system, in this case the periodontal pocket (Wimpenny \& Necklen 1971), expressed in millivolts $(\mathrm{mV})$. The more reduced the environment, the lower (i.e., the more negative) the Eh. One study has recorded redox potentials as low as $-300 \mathrm{mV}$ in periodontal pockets (Aranki et al. 1969), compared with an Eh of $+200 \mathrm{mV}$ in aerobically metabolizing tissues and $+70 \mathrm{mV}$ in the healthy gingival crevice (Kenney \& Ash 1969). Ewers \& Greener (1985), studying the electrochemical activity of the oral cavity, found that periodontal pockets deeper than $4 \mathrm{~mm}$ had the most negative $E h$ and concluded that this would help the proliferation of anaerobic bacteria. As the $\mathrm{OO}_{2}$ of the environment decreases (as in a deepening periodontal pocket) the $\mathrm{Eh}$ becomes more negative. This is due firstly to oxygen consumption by facultative and aerobic (or microaerophilic) bacteria and later to hydrogen production by the anaerobic organisms. Other studies have confirmed this concept (Finegold 1989) and have shown that anaerobic spirochaetes will grow only in the presence of supporting (facultative) organisms which were able to reduce the Eh of the medium and provide "growth factors"; the same anaerobes were not capable of similar growth in isolation (Socransky et al. 1964). Once conditions suitable for the growth of anaerobic organisms have been achieved in this way they are then able to further reduce the $E$ h of their environment by their own, hydrogenproducing, metabolism (Kenney \& Ash 1969, Smith \& Williams 1984). Some spirochaetes, considered to be closely associated with the pathogenesis of periodontitis, require a particularly low and narrow Eh range in which to grow $(-185 \mathrm{mV}$ to $-220 \mathrm{mV})$, although other anaerobes are able to grow over a wider, but still low, Eh range (Socransky et al. 1964). Many of the diseaserelated anaerobes, which can be shown in culture to have a marked sensitivity to oxygen and a raised $\mathrm{Eh}$, may survive in vivo due to the presence of an accom- panying microbial population which may change the nature of the local environment by the respiratory removal of oxygen, the lowering of the Eh, metabolic activity or the excretion of vitamins, growth factors and enzymes. The result is that the anaerobes may have an effective means of protection against oxygen (and the associated high Eh) in mixed microbial populations (Pfennig 1979). However, since $90 \%$ of the subgingival microflora in periodontal pockets comprises strict anaerobes (Slots 1977), one may speculate that this particular ecosystem, without

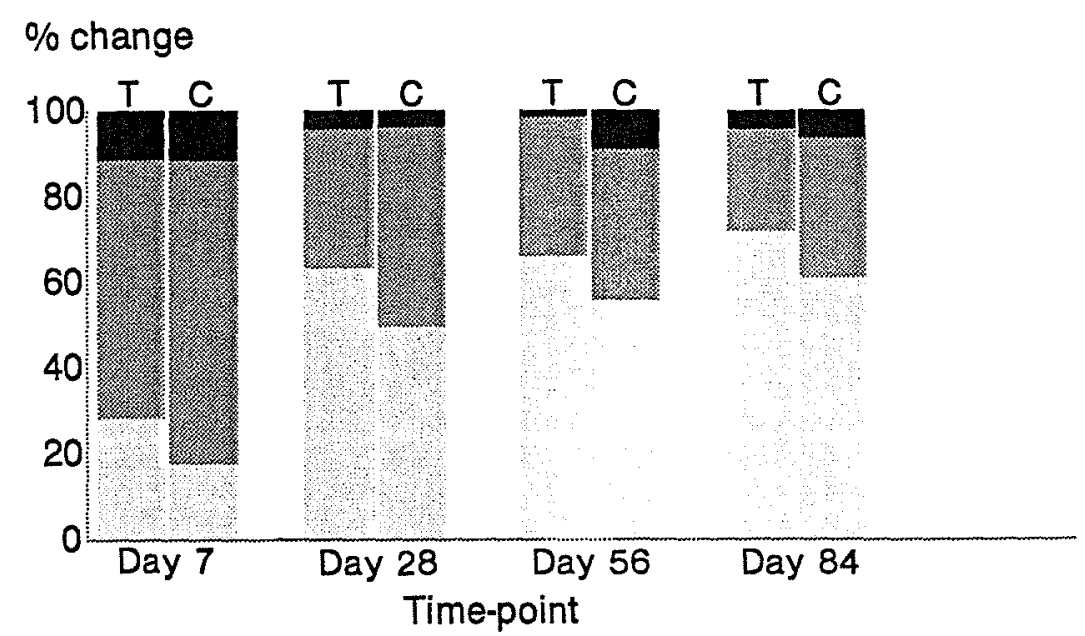

\section{Improvement 禨 No Change Deterioration \\ $T=$ Test $\quad C=$ Control}

Fig. 3. Probeable pocket depth: \% change from baseline for each time-point.

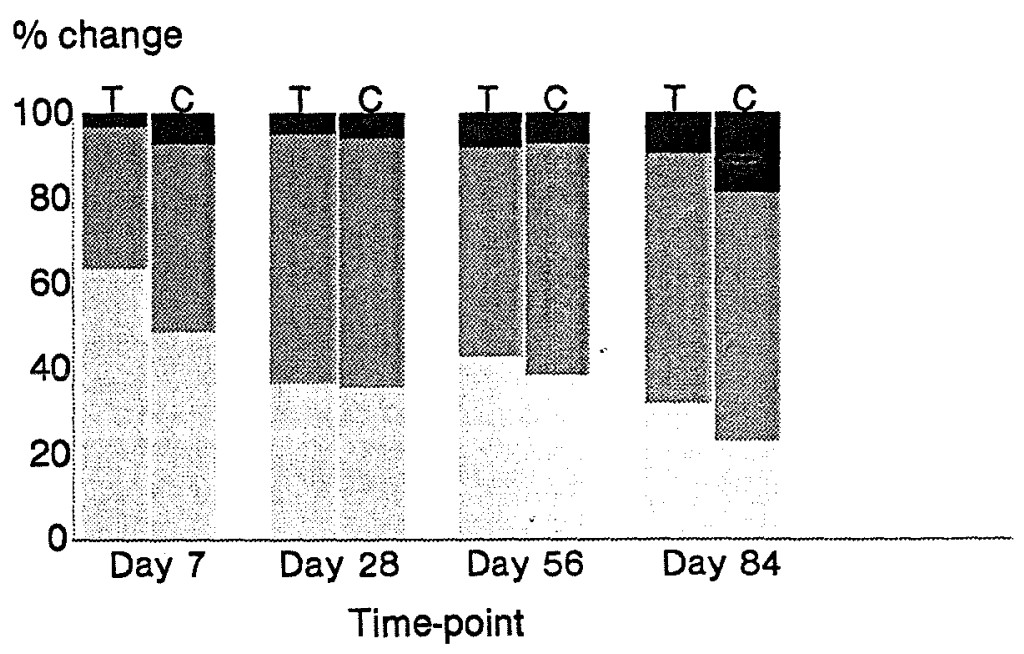

\section{Improvement No Change Deterioration $\mathrm{T}=$ Test $\mathrm{C}=$ Control}

Fig. 4. BANA test (perioscan): \% change from baseline for each time-point. 


\section{$\%$ change}

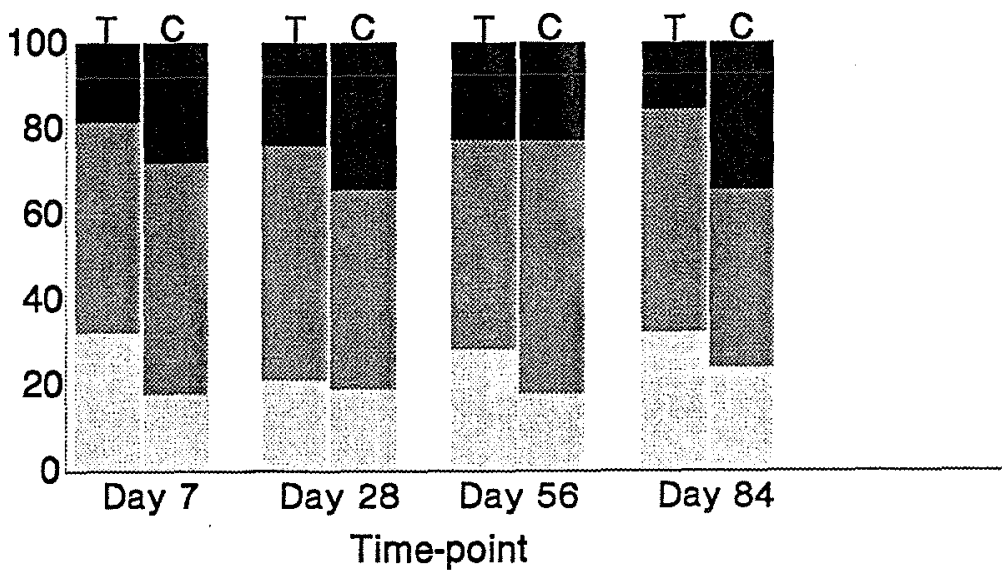

\section{Improvement 變 No Change Deterioration \\ $\mathrm{T}=$ Test $\quad \mathrm{C}=$ Control}

Fig. 1. Plaque index: \% change from baseline for each time-point.

$\chi^{2}$ tests carried out for PII, PPD and BANA revealed no significant betweengroup differences at the $95 \%$ confidence level, but for BOP the test group had a significantly greater bleeding tendency.

\section{Site-based data}

For PlI, percentage changes from baseline for each time point (Fig. 1) showed a tendency for the test group to have a greater proportion of sites improving and a smaller proportion deteriorating in relation to baseline. Both groups showed a clear tendency for reducing BOP during the study: at the start both exhibited BOP from all sites but by day 84 there was no bleeding in nearly $60 \%$ of sites. There was a distinct trend for the test group to show a greater proportion of improving sites and a reduced proportion of deteriorating sites at all time points except day 28 (Fig. 2). By day 84, there were minimal betweengroup differences, with most sites having shown improvement $(80.3 \%$ test, $79.7 \%$ control) and only very low percentages showing deterioration (1.4\% test, $2.5 \%$ control).

At baseline, the distribution of pocketing was very similar between the groups for most depths, the exception being $7 \mathrm{~mm}$ pockets which were more prevalent in test group $(14.0 \%)$ than control $(7.6 \%)$. In both groups probing pocket depths reduced considerably over the study period (Fig. 3). Both groups showed an increase in the percentage of sites improving from day 7 onwards. At each time-point the test group showed a consistently greater proportion of improving sites, the difference being approximately $10 \%$ at most time-points and $14 \%$ at day 28 . By day 84 , approximately $72 \%$ of test sites and $61 \%$ of control sites had improved in comparison to baseline.

The BANA test results showed that, for both groups, the highest proportion of sites scoring positive (test $73.0 \%$, control $64.3 \%$ ) and the lowest proportion scoring negative (test $1.6 \%$, control $1.4 \%$ ) were recorded at baseline.

\section{$\%$ change}

\section{$\mathrm{T}=$ Test $\quad \mathrm{C}=$ Control}

At day 7, positive scores then showed a marked decrease in both groups, gradually increasing up to day 84 . Conversely, negative scores were greatly increased at day 7 in both groups, following which they decreased at each successive timepoint. By day 84 in comparison to baseline the test group had $9 \%$ more sites improved, and $9.1 \%$ fewer sites deteriorated, compared to the control group (Fig. 4). The test group consistently displayed a higher percentage of improving sites compared to control.

\section{Subject-based data}

Differences between the groups were significant at a number of time-points (see Table 1). For PII, significantly greater improvements were found in the test group at 2 time-points: at days 7 $(\mathrm{SND}=2.877)$ and $84(\mathrm{SND}=2.559)$. The difference in BOP between test and control was highly significant at day 56 $(\mathrm{SND}=3.278)$ in favour of the test group. For PPD, at day 56 there was a significant difference between groups $(\mathrm{SND}=2.447$ ), again in favour of the test group. There was also a significantly greater improvement in the BANA results for the test group at day 7 $(\mathrm{SND}=2.776)$.

\section{Discussion}

This study investigated a chemical adjunct that might reduce the need for meticulous self-administered plaque

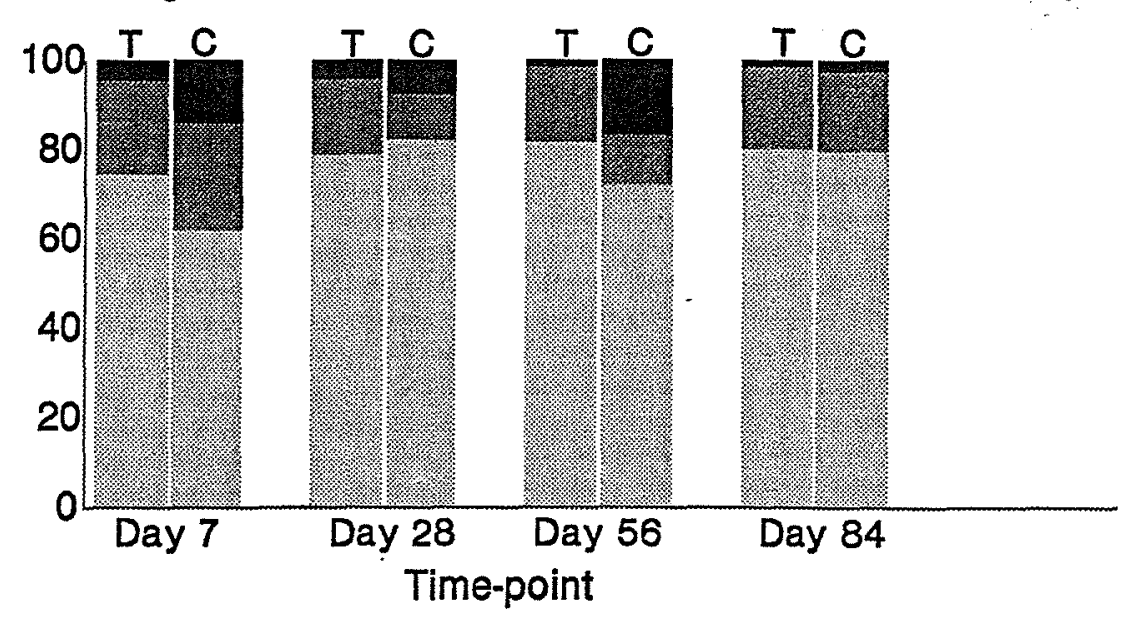

\section{Improvement No Change Deterioration}

Fig. 2. Bleeding index: \% change from baseline for each time-point. 


\section{Résumé}

Effers sur la parodontite' chronigute d'un agen Redox place en position sous-gingirale dans un dispositif a libiration lente

L'utilisation dagents chimiques adjuvants peut diminuer la nécessité de réaliser un contrôle méticuleux de la plaque. Le but de la présente étude était d’évaluer le potentiel de traitement parodontal que représente l'application sous-gingivale dun agent redox, le bleu de méthylène, dans un dispositif à libération lente. Cette étude randomisée, en simple aveugle et en "bouche divisée" (splitmouth), portait sur 18 patients âgés de 35 57 ans, atteints de parodontite chronique de l'adulte, avec des poches d'au moins $5 \mathrm{~mm}$ et chez qui on constatait une perte osseuse certaine sur les radiographies. Tous les sites de l'expérience ont subi un débridement sous-gingival au jour 0 . Les sites expérimentaux (Test $=\mathrm{T}$ ) ont reçu du bleu de méthylène à $32 \%$ en poids dans le dispositif à libération lente aux jours 0 et 28 . L'examen clinique et le prélèvement microbiologique ont été pratiqués aux jours $0,7,28,56$ et 84 . Des améliorations cliniques ont été vues dans les 2 groupes, mais les sites tests présentaient régulièrement les améliorations les plus grandes, certaines dentre elles étant statistiquement significatives (d'après les comparaisons entre groupes à l'aide du SND). Des différence significatives entre les groupes par rapport aux valeurs initiales ont été constatées pour l'indice du saignement aux jours 7 et 56 , pour les profondeurs de poches au sondage au jour 56 et pour le test Perioscan BANA au jour 7. Cette étude préliminaire a donc montré que le bleu de méthylène utilisé comme adjuvant dans un dispositif à libération lente peut produire des améliorations cliniques et microbiologiques plus fortes que le débridement sous-gingival seul.

\section{References}

Addy, M. (1986) Chlorhexidin compared with other locally delivered antimicrobials. $J$ Clin Periodoniol 13, 957-964.

Aranki, A., Syed, S. S., Kenney, E. B. \& Freter, R. (1969) Isolation of anaerobic bacteria from human gingiva and mouse caecum by means of a simplified glove box procedure. Appl Microbiol 17, 568-576.

Armitage P. \& Berry, G. (1987) Statistical methods in medical research, 2 nd edition. Oxford, Blackwell.

Axelsson, P. \& Lindhe, J. (1978) Effect of controlled oral hygiene procedures on caries and periodontal disease in adults. $J$ Clin Periodontol 5, 133-151.

Baer, P. N., Cox, D. S., Ference, R. \& Kitzis, S. (1985) A method for altering the periodontal pocket environment from anaerobic to aerobic. Periodontol Case Reports 7, 6-10.

Bland, J. M. \& Altman, D. G. (1986) Statistical methods for assessing agreement between two methods of clinical measurement. Lancet i, 307-310.
Box, H. K. (1937) The Dunlop method of insufflation in periodontal therapeutics. Oral Health 27, 447-457.

Cohen, J. (1960) A coefficient of agreement for nominal scales. Educ Psych Measurement 20, 37-46.

Coventry, J. \& Newman, H. N. (1982) Experimental use of a slow release device employing chlorhexidine gluconate in areas of acute periodontal infammation. $J$ Clin Periodontol 9, 129-133.

Dunlop, W. F. (1913) Pyorrhea and its treatment. Chicago, Dunlop Research Institute.

Dzink, J. L., Socransky, S. S. \& Haffajee, A. D. (1988) The predominant cultivable microbiota of active and inactive lesions of destructive periodontal diseases. $J$ Clin Periodontol 15, 316-323.

Ewers, G. J. \& Greener, E. H. (1985) The electrochemical activity of the oral cavity a new approach. $J$ Oral Rehab 12, 469476.

Finegold, S. M. (1969) Classification and taxonomy of anaerobes. In: Finegold, S. M. \& George, W. L. (eds.): Anaerobic infections in humans. San Diego: Academic Press, p. 23-36.

Gibson, M., Mangat, D., Gagliano, G., Wilson, M., Fletcher, J., Bulman, J. \& Newman, H. (1992) Methylene blue and subgingival flora. $J$ Dent Res 71,550 , abstr.

Goodson, J. M. Hogan, P. \& Dunham, S. (1984) Clinical responses in a 4-quadrant study of periodontal therapy. $J$ Dent Res 63, 268, abstr.

Gotsko, E. V., Palamarchuk, V. N. \& Myskiv, O. V. (1980) Experience in the use of hyperbaric oxygen in the combined therapy of parodontal disease. Stomatologiia 59. 23-24.

Granick, M. S., Heckler, F. R. \& Jones, E. W. (1987) Surgical skin marking techniques. Plast Reconstr Surg 79, 573-580.

Greenstein, G. (1984) The role of bleeding upon probing in the diagnosis of periodontal disease. $J$ Periodontol 55, 684-688.

Guentherman, R. H., Bishop, J. G., Collings, K. C. \& Dorman, H. L. (1972) The effect of increased blood oxygen tensions on induced periodontal disease. $J$ Periodontol 43, 233-236.

Haskel, E., Esquenasi, J. \& Yussim, L. (1986) Effects of subgingival chlorhexidine irrigation in chronic moderate periodontitis. $J$ Periodontol 57, 305-310.

Hirsch, R. S., Clarke, N. G. \& Townsend, G. C. (1981) The effect of locally released oxygen on the development of plaque and gingivitis in man. J Clin Periodontol 8, 2128.

Jacob, H. E. (1970) Redox potential. Methods Microbiol 2, 91-123.

Jacob, H. E. (1974) Reasons for the redox potential in microbial cultures. Biotechnol \& Bioeng Symposium, no 4, 781-788.

Kaslick, R. S., Shapiro, W. B. \& Chasens, A. I. (1975) Studies on the effects of a urea peroxide gel on plaque formation and gingivitis. J Periodontol 46, 230-232.

Katsanoulas, T. Renee, I. \& Attstrom, R.
(1992) The effect of supragingival plaque control on the composition of the subgingival flora in periodontal pockets. $J$ Clin Periodontol 19, 760-765.

Kenney, E. B. \& Ash, M. M. (1969) Oxidation-reduction potential of developing plaque, periodontal pockets and gingival sulci. J Periodontol 40, 630-633.

Keyes, P. H., Wright, W. E. \& Howard, S. A. (1978a) The use of phase-contrast microscopy and chemotherapy in the diagnosis and treatment of periodontal lesions - an initial report (1). Quintessence Int 9, 5156.

Keyes, P. H., Wright, W. E. \& Howard, S. A. (1987b) The use of phase-contrast microscopy and chemotherapy in the diagnosis and treatment of periodontal lesions - an initial report (2). Quintessence Int 9, 6976.

Keyes, P. H., Love, L., Mercer, P. \& Krichevsky, M. I. (1982a) Microbial community structure as an indicator of therapeutic progress in treatment of destructive periodontitis. J Dent Res(abstr. 1224) 61, 314 .

Keyes, P. H. (1982b) Microbiologically modulated periodontal therapeutics: an introduction. Quintessence Int 13, 13211325.

Khoo, J. G. L. \& Newman, H. N. (1983) Subgingival plaque control by simplified oral hygiene regime plus local chlorhexidine or metronidazole. J Clin Periodontol 18,607619.

Linden, G. J. \& Newman, H. N. (1991) The effects of subgingival irrigation with low dosage metronidazole on periodontal inflammation. $J$ Clin Periodontol 18, 177 181.

Lindhe, J., Liljenberg, B., Adielson, B. \& Borjesson, I. (1983) Use of metronidazole as a probe in the study of human periodontal disease. $J$ Clin Periodontol 10 $100-112$.

Lindhe, J., Westfelt, E., Nyman, S. Socransky, S. S. \& Haffajee, A. D. (1984) Longterm effect of surgical/non-surgical treatment of periodontal disease. $J$ Clin Periodontol 11, 448-458.

Listgarten, M. A. \& Helldén, L. (1978) Relative distribution of bacteria at clinically healthy and periodontally diseased sites in humans. J Clin Periodontol 5, 115-131.

Löe, H. \& Schiott, C. R. (1970) The effect of mouthrinses and topical application of chlorhexidine on the development of dental plaque and gingivitis in man. $J$ Periodont Res 5, 79-83.

Locsche, W. J., Gusberti, F., Mettraux, G., Higgins, T. \& Syed, S. (1983) Relationship between oxygen tension and subgingival bacterial fiora in untreated periodontal pockets. Inf Imm 42, 659-667.

Marsh, P. \& Martin, M. (1984) Oral microbiology, 2nd edition. Woking: Van Nostrand Rheinhold, pp. 5-7.

McNabb, H., Mombelli, A. \& Lang, N. P. (1992) Supragingival cleaning 3 times a week - microbiological effects in moder- 
the protection of oxygen-scavenging species to any significant degree, may be especially vulnerable to oxygen or the effects of a raised Eh. Redox agents are substances which, while not actually releasing oxygen, are able to raise the redox potential of their environment by acting as electron acceptors and thus causing a degree of oxidation of the environment, in this case the periodontal pocket. The effect of an increased Eh on anaerobes is to reduce the energygenerating capacity of the organism by shifting redox couples to a more oxidised state, disrupting redox-dependent enzyme systems and consuming essential metabolic reducing power (Morris 1980). The redox dyes, of which methylene blue is an example, are coloured when oxidized and colourless when reduced, and have been used to stain fistulae and sinus tracts in diagnostic procedures, and for skin marking prior to surgery (Granick 1987). Methylene blue has no major side-effects and is used in the treatment of methaemoglobinaemia and urolithiasis. The Eh of fully-oxidized methylene blue is $+71 \mathrm{mV}$ and in this form it acts as an oxidising agent. When $50 \%$ reduced its $\mathrm{Eh}$ is $+11 \mathrm{mV}$. In this state, methylene blue can act as a redox-poising agent, or buffer, maintaining the Eh at a particular level depending on the relative oxidation-reduction capacities of the agent and its surroundings. This level would be somewhere between $+11 \mathrm{mV}$ and the $\mathrm{Eh}$ of the pocket and may be too high to be compatible with the growth and metabolism of many anaerobic bacteria.

For ethical reasons no placebo carrier was used on the control side during the course of the study and, in any event, previous research indicates that carriers may actually increase inflammation (Coventry \& Newman 1982).

Methylene blue in a slow release carrier appears to have been of benefit when used as an adjunct to mechanical therapy, proving to be more effective than mechanical therapy alone. Studies investigating the adjunctive use of other locally released chemical agents have produced similar results. Goodson et al. (1984) and Heijl et al. (1991) found that scaling plus locally released tetracycline was more effective than scaling alone, and Khoo \& Newman (1983) reported similarly, comparing the local subgingival release of metronidazole and chlorhexidine as adjuncts to mechanical therapy. The main advantage of the agent used in this study, unlike these other antimicrobial agents, is that development of resistance in, or overgrowth by, the target organisms would be extremely unlikely as this would require radical changes in the organisms' metabolic processes.

Although this study has shown that locally released methylene blue exerted a beneficial therapeutic effect, the results may have been influenced by two other factors; firstly, the properties of the slow release carrier were unknown so there was no way of determining over what time period the agent would be released. The agent may have been released in a relatively short period. Secondly, the frequency of application was chosen on the basis of convenience for the patient, rather than on any scientific criteria. Clearly, this aspect needs further investigation.

The clinical use of methylene blue in the treatment of chronic periodontitis has been investigated in 2 previous studies. In one (Wilson et al. 1992), which involved 7 patients for 14 days, test sites received daily subgingival methylene blue in an aqueous gel for the first 7 days, while control sites received sterile water. Clinically, GCF flow decreased significantly in the test group but no significant differences were found between test and control sites in terms of bleeding on probing or pocket depth, perhaps because changes would have to have been marked to have been detected. Pocket depths were less $(4-7 \mathrm{~mm})$ than in the present study, implying less severe periodontitis and thus a reduced potential to show clinical change on such a short time-scale. No subgingival instrumentation was carried out in this study and the present study found that it was the adjunctive action of methylene blue that had the most beneficial effect. The main similarity in the two studies was the change in the subgingival flora, which in both studies suggested an early shift towards periodontal health.

Similar microbiological improvements were found in another study (Gibson et al. 1992) in which 25 patients received, in one site per quadrant, either $1 \%$ methylene blue or water by irrigation once daily for 28 days, $32 \%$ methylene blue in a slow release carrier at days 0,7 and 28 , or baseline subgingival debridement alone. This study concluded that methylene blue, in either form, was superior to a single thorough subgingival debridement in reducing subgingival anaerobes.
It can therefore be concluded from the present study that the redox agent methylene blue, in a subgingivallyplaced slow release carrier, has the potential to enhance the effects of mechanical instrumentation and thus reduce the need for meticulous interproximal plaque control in patients with routine chronic adult periodontitis. As a dye, it may be unacceptable to patients, even in the present slow release form and even though colourless in the reduced state. Other redox agents, perhaps with higher redox potentials and without the tendency to stain the oral tissues, even transiently, require investigation.

\section{Acknowledgement}

We wish to thank Dr. W. Harvey, Johnson \& Johnson, Stirling, Scotland, for preparation and supply of the redox agent in its carrier form.

\section{Zusammenfassung}

Die Wirkung eines subgingival mittels Medikamententräger eingesetzten Redoxstoffes auf die chronische Parodontitis

Als Adjuvanz eingesetzte chemische Wirkstoffe können den Bedarf an sorgfältiger Plaqueentfernung reduzieren. Das Ziel dieser Studie war es, die Möglichkeit einer parodontalen Behandlung durch den subgingivalen Einsatz mittels eines Medikamententrägers des Redoxstoffes Methylenblau zu beurteilen. Diese randomisierte, einfachblinde Split-Mouth-Studie wurde mit 18 Patienten im Alter zwischen 35 und 57 Jahren und vorhandener chronischer Erwachsenenparodontitis durchgeführt. Die Taschentiefe betrug wenigstens $5 \mathrm{~mm}$ bei röntgenologisch gleichmäßigem Knochenabbau. In allen experimentellen Taschen wurden an Tag 0 .ein Scaling und Wurzelglättung durchgeführt. Die Testtaschen bekamen den Medikamententräger mit $32 \% \mathrm{w} / \mathrm{w}$ Methylenblau an Tag 0 und 28. Klinische Untersuchungen und mikrobiologische Probenentnahme wurden an Tag 0, 7, 28, 56 and 84 durchgefuhrt. In beiden Gruppen wurden klinische Verbesserungen beobachtet, aber die Testtaschen zeigten beständig größere Verbesserungen, von denen einige statistisch signifikant waren (entsprechend der Auswertung von Gruppenvergleichen mittels SND-Test). Im Verhältnis zu den Ausgangswerten gab es signifikante Unterschiede zwischen den Gruppen hinsichtlich des Blutungsindex an Tag 7 und 56, bei der Sondierungstiefe an Tag 56 und für den Perioscan BANA-Test an Tag 7. Daher zeigte diese Pilosttudie, daß der Einsatz eines Medikamententrägers mit Methylenblau als Adjuvanz eine größere klinische und mikrobiologische Verbesserung bewirkt als alleiniges subgingivales Scaling mit Wurzelglättung. 
ately deep pockets. $J$ Clin Periodontol 19 , 348-356.

Mettraux, G. R., Gusberti, F. A. \& Graf, H. (1984) Oxygen tension $\left(\mathrm{pO}_{2}\right)$ in untreated human periodontal pockets. $J$ Periodontol 55, 516-521.

Morris, J. G. (1980) Oxygen tolerance/intolerance of anaerobic bacteria. In: Gottschalk, G., Pennig, N. \& Werner, H. (eds.): Anaerobes and anaerobic infections. New York: Fischer Verlag, pp. 7-15.

Nyman, S., Rosling, B. \& Lindhe, J. (1975) Effect of professional tooth cleaning on healing after periodontal surgery. $J$ Clin Periodontol 2, 80-86.

O'Leary, T. J. (1980) Plaque control. In: Shanley, D. B. (ed.): Efficacy of treatment procedures in periodontics. Qunintessence Publishing Co Inc., p. 41-53.

Pfennig, N. (1979) Formation of oxygen and microbial processes establishing and maintaining anaerobic environments. In: Shilo, M. (ed.): Strategies of microbial life in extreme environments. Berlin: Dahlem Konferenzen, pp. 137-148.

Rosling, B. G., Slots, J., Webber, R. L., Chrissterson, L. A. \& Genco, R. J. (1983) Microbiological and clinical effects of topical subgingival antimicrobial treatment on human periodontal disease. $J$ Clin Periodontol 10, 487-514.

Sackett, D. L. (1976) The magnitude of compliance and non-compliance. In: Sackett, D. L. \& Haynes, R. B. (eds.): Compliance with therapeutic regimens. Baltimore: John Hopkins University Press, p. 16.

Saxer, U. P. \& Muhlemann, H. R. (1975) Motivation und Aufklärung. Schweiz Mschr Zahnheilk 85, 905-919.

Sbordone, L., Ramaglia, L., Gulletta, E. \& Iacono, V. (1990) Recolonization of the subgingival microflora after scaling and root planing in human periodontitis. $J$ Periodontol 61, 579-584.

Shapiro, W. B., Kaslick, R. S. \& Chasens, A. I. (1973) The influence of urea peroxide gel on plaque, calculus and chronic gingival inflammation. $J$ Periodontol 44, 636-639.
Shipman, B., Cohen, E. \& Kaslick, R. S. (1971) The effect of a urea peroxide gel on plaque deposits and gingival status. $J$ Periodontol 42, 283-285.

Silness, J. \& Löe, H. (1964) Periodontal disease in pregnancy (II). Correlation between oral hygiene and periodontal condition. Acta Odontol Scand 24, 747-759.

Slanetz, L. W. \& Brown, E. A. (1946) Studies of the effect of glycerite of hydrogen peroxide upon the numbers of oral micro-organisms. $J$ Dent Res 25, 223-230.

Slots, J. (1977) The predominant cultivable microflora of advanced periodontitis. Scand J Dent 85, 114-121.

Slots, J. (1979a) Subgingival microflora and periodontal disease. $J$ Clin Periodontol 6, 351-382.

Slots, J., Mashimo, P., Levine, M. J. \& Genco, R. J. (1979b) Periodontal therapy in humans. I. Microbiological and clinical effects of a single course of periodontal scaling and root planing, and of adjunctive tetracycline therapy. $J$ Periodontol 50, 495509.

Smith, L. D. S. \& Williams, B. L. (1984) Anaerobes and the toxic effect of oxygen. In: The pathogenic anaerobic bacteria, 3 rd edition. Springfield, Thomas, pp. 12-17.

Socransky, S. S., Loesche, W. J., Hubersak, C. \& MacDonald, J. B. (1964) Dependency of Treponema microdentium on other oral organisms for isobutyrate, polyamines and a controlled oxidation-reduction potential. $J$ Bacteriol 88, 200-209.

Socransky, S. S. (1977) Microbiology of periodontal disease - present status and future considerations. J Periodontol 48, 497-504.

Socransky, S. S., Tanner, A. C. R., Haffajee, A. D., Hillman, J. D. \& Goodson, J. M. (1982) Present status of studies on the microbial aetiology of periodontal diseases. In: Genco, R. J. \& Mergenhagen, S. E. (eds.): Host-parasite interactions in periodontal disease. Washington: American Society for Microbiology, pp. 1-12.

Steiner, B., McClean, I. \& Graves, S. (1981) Redox potential and survival of virulent
Treponema pallidum under microaerophilic conditions. Br J Ven Diseases 57, 295-301.

Sumachev, V. I. (1983) Hyperbaric oxygenation in the combined therapy of periodontosis. Stomatologiia 62, 22-24.

Wade, W. G., Moran, J., Morgan, J. R., Newcombe, R. \& Addy, M. (1992) The effects of antimicrobial acrylic strips on the subgingival microflora in chronic periodontitis. J Clin Periodontol 19, 127-134.

Waerhaug, J. (1976) The interdental brush and its place in operative crown and bridge dentistry. J Oral Rehabil 3, 107-113.

Wennstrom, J. L., Heijl, L., Dahlen, G. \& Grondahl, K. (1987a) Periodic subgingival antimicrobial irrigation of periodontal pockets (I) Clinical observations. J Clin Periodontol 14, 541-550.

Wennstrom, J. L., Dahlen, G., Grondahl, K. \& Heijl, L. (1987b) Periodic subgingival antimicrobial irrigation of periodontal pockets (II). Microbiological and radiographic observations. $J$ Clin Periodontol 14, 573-580.

Wilson, M., Gibson, M., Strahan, J. D. \& Harvey, W. (1992) A preliminary evaluation of the use of a redox agent in the treatment of chronic periodontitis. $J$ Periodont Res 27, 522-527.

Wimpenny, J. W. T. \& Necklen, D. K. (1971) The redox environment and microbial physiology (I). The transition from anaerobiosis to aerobiosis in continuous cultures of facultative anaerobes. Biochim Biophys Acta 253, 352-359.

Address:

P. C. Ower

Institute of Dental Health and Training RAF Halton

Aylesbury, Bucks HP225PG

UK 